\title{
The Effect of Artistic Gymnastics Talent Scouting Application to Artistic Gymnastic Basic Skills
}

\author{
Endang Rini Sukamti \\ Faculty of Sport Sciences \\ Universitas Negeri Yogyakarta \\ Yoyakarta, Indonesia \\ endang_fik@uny.ac.id
}

\author{
Sebastianus Pranatahadi \\ Faculty of Sport Sciences \\ Universitas Negeri Yogyakarta \\ Yoyakarta, Indonesia \\ endang_fik@uny.ac.id
}

\begin{abstract}
- the development of gymnastics athlete performance in Indonesia did not show significant progress over the years. Talent scouting is the important basic in achieving optimal performance. The aim of this study is to determine the effect of Artistic Gymnastics Talent Scouting Application to Artistic Gymnastic Basic Skills. A descriptive qualitative method study was developed using a survey technique. The sample was defined as 100 students, with 7-9 years old from Sleman area. Tests and measurements of anthropometry, biomotor, and gymnastic basic skills were used as data collection techniques. The early age artistic gymnastic talent scouting software was used as data analysis techniques with the aim to determine the category of talented sample research. The results showed that there are 3 talented students, 46 students are quite talented, 50 less talented students, and 1 student is not talented. The results showed that there is no significant effect of Artistic Gymnastics Talent Scouting Application to Artistic Gymnastic Basic Skills $(\mathrm{p}=$, 214).
\end{abstract}

Keywords—artistic gymnastics, talent scouting, basic skills

\section{INTRODUCTION}

The early age talent scouting is done with the aim to find children with talents and potentially ready to be trained and fostered to become outstanding individuals. Various efforts have been made by the government and competent people in the process to explore and find talented children in all fields. Moreover, in the field of sports, each sport has standards and measuring instruments to find gifted children. In general, talent scouting in sports is carried out with several tests including anthropometric measurements and biomotor tests. Artistic gymnastics is a poly structural, conventional sport based on complex movements, performed in accordance with aesthetic criteria and strictly defined rules [1]. There is a need to include in artistic gymnastics talent scouting instrument different factors.

Anthropometric measurement gymnastics includes weight, height, arm span, sitting height, leg length, chest circumference, pelvic circumference, and body mass index. Biomotor tests consist of the selectivity (sit and reach, side split and bridge/bridge attitude), balance, strength (push ups, sit ups and chin ups), power (standing broad jump/jump without prefix), and agility.

Another factor that we can make as a guideline in talent scouting is the artistic movement basic movement skills. Basic movement skills are the ability to carry out movements efficiently and effectively, as a result of the control and coordination of body parts involved in the movement. Movement skills are obtained from the process of learning motion. The reach of a certain level of skill requires a long time different for each individual depending on the talent. There are some basic movement skills in artistic gymnastic including forwarding roll, twisting, and bending movement.

Olaru suggests that the role of selection in performance sports is to choose children with most talented skills and qualities from a large number of children [2]. Gymnastics is considered a sport with complex techniques. Its practice requires special qualities for anyone who wants to achieve extraordinary results in this sport. One of the determinants of value in excellent artistic performance is the process of selecting and training children and junior-level gymnasts. Selection is the basis of exercise performance. Early selection of gymnastics exercises performed at 6 years old only reveal the skills of the subject being investigated. Olaru suggests that the success in the selection process is related to the concept and personal experience of the models, methods, standards, experiments used, and maintenance of the ideal ability [2]. Athletes are a decisive factor in achievement. The selection of athletes through talent identification and development must be done in early years.

Children aged 7-9 years are educated in elementary school (SD). The proximity of the sports teacher can make it easier to do selection/selection. The sports teacher is also a trainer, so he is going to be more careful of children who have more skills than the other friends. The teacher as a trainer is accustomed to providing special training which is accommodated in Pengkab, Persani Sleman which has a gymnastics club. Thus the network can be designed with the collaboration between researchers and trainers, teachers, Pengkab Persani Sleman and Pengda Persani DIY.

Endang has found a model for developing talent scouting through gifted software applications [3]. The existence of early artistic gymnastics, giftedness software helps to facilitate the search for gifted children especially, in gymnastics. In this application, users only need to do tests and measurements( biomotor tests and anthropometric measurements) The existence of application form of talent scouting software can help the research team to explore deeply the basic skills including forwarding roll, twisting and bending the body with 
hands touching the floor. For this reason, our study tried to identify a correlation between findings obtained through artistic gymnastics gifted software applications and findings obtained with basic test basic skills tests.

\section{METHODS}

A descriptive quantitative method was used in this research, using a sample of 100 students, with 7-9 years old, students from Sleman area. The following exclusion criteria were applied: a student from Sleman elementary school, no health problems or injuries, a school without gymnastics extracurricular activity. The sampling technique was based on purposive sampling, chosen specifically based on research objectives [4].

Measurements of anthropometry and biomotor were done. The test instruments in this study consisted of anthropometric measurements which included height, weight, sitting height, arm span, leg length, chest circumference, pelvic circumference, and BMI. While biomotor tests included flexibility (sit and reach, bridge/bridge attitudes), balance, strength (push ups, sit ups and chin ups), power, and agility. The obtained data were analyzed using an artistic gymnastic gift software application at an early age. The data analysis techniques used in our study was a regression test.

Several tests can be done with the aim to identify the basic skills of artistic gymnastics in early childhood. Examples of basic gymnastic skills tests are a forward roll, twisting and bending over. Retrieval of basic skills data is carried out by 3 (three) judgments with scoring guidelines. Early age artistic gymnastic talent scouting software determined the category of talented sample research.

\section{RESULT AND DISCUSSION}

The results of the measurement of 100 elementary school students in Sleman Regency were obtained. The data obtained from these measurements were analyzed by simple correlation regression techniques. The Measurements results can be evaluated in Table I.

TABLE I. TALENT SCOUTING ANALYSIS RESULT

\begin{tabular}{|c|c|c|}
\hline Category & Frequency & Percentage (\%) \\
\hline Very Talented & 0 & 0 \\
\hline Talented & 3 & 3 \\
\hline Quite Talented & 46 & 46 \\
\hline Less Talented & 50 & 50 \\
\hline t Talented & 1 & 1 \\
\hline
\end{tabular}

Table I shows the results of the screening of Sleman District Elementary School students' gymnastic talent. The result can be divided into generally less talented (50\%) and quite talented $(46 \%)$, while the talented students were only $3 \%$ of the total students and $1 \%$ were included in the category not talented.
The data related to the level of gymnastics skills were obtained from the test of forwarding roll, twisting, and bending. The results of the basic skill test can be seen in

TABLE II. BASIC SKILl TEST RESUlT

\begin{tabular}{|l|c|c|}
\hline \multicolumn{1}{|c|}{ Category } & Frequency & Percentage (\%) \\
\hline$<5$ poin & 38 & 38 \\
\hline$>5$ poin & 62 & 62 \\
\hline
\end{tabular}

\section{A. Prerequisite Test}

Regression analysis test requirements are procedures that should be implemented and fulfilled. Regression test requirements are the normality test, the homogeneity test, and linearity test.

\section{B. Normality test}

The normality test in this study used Kolmogorov Smirnov, using SPSS. The results of the normality test showed that the research data distribution was normalized. Gifted data was normally distributed with a significance of 0.549 , while skill data was normally distributed with a significance level of 0.896 .

\section{Homogeneity Test}

The variance homogeneity test was used to define if the obtained data was homogeneous or not. The test used was the chi-square. The homogeneity test results showed that the overall research data was homogeneous. Gifted data was having a significance of 0.649 , while the skill data was normally distributed with a significance level of 0.730 .

\section{Linearity Test}

Linearity test is intended to determine whether or not linear independent variable data with the dependent variable. The results of this analysis were used as a consideration whether the obtained data can be analyzed using regression analysis. The results of the normality test showed that the entire research data was linear. The level of significance of giftedness was 0.038 , while the skill data was normally distributed with a significance level of 0.047 .

\section{E. Linear Regression Test}

Hypothesis testing used in this study examined the relationship between talent scouting test and basic gymnastic skill performed by linear regression analysis. The results of linear regression analysis can be observed in Table III

TABLE III. LINEAR REGRESSION TEST

\begin{tabular}{|l|c|c|}
\hline \multicolumn{1}{|c|}{ Variabel } & F & Sig \\
\hline $\begin{array}{l}\text { Talent Scouting Test* } \\
\text { Gymnastic skill test }\end{array}$ & 1.568 & 0.214 \\
\hline
\end{tabular}


The results of the regression analysis showed the significance level of $0.214>0.05$. As we can see there was no significant correlation or relationship between the results of giftedness tests with basic gymnastic skills.

The results showed that there was no significant relationship between giftedness tests and basic gymnastic skills.

The level of gymnastic skills is influenced by several factors including the relevant physical quality, psychological quality, and one's intelligence. Other factors beyond physical quality like the psychological condition of the research subject may have an influence on the results of basic gymnastic skills. As a result, if a person's psychological condition is not good it will reduce the appearance of exercising.

\section{CONCLUSION}

Gymnastics is a complex sport. Many factors are needed to identify talented children in the field of gymnastics. These factors can be used as indicators in the manufacture of instruments for the training of gymnastic talent, including anthropometry, physical, psychological and basic skills in gymnastics. Factors that are used as indicators in the manufacture of instruments for the training of gymnastic talent, including anthropometry, physical, psychological and basic skills in gymnastic.

\section{REFERENCES}

[1] Aleksandra, Kamenka, Lucija, Marko, Marijo, "The infuence of anthripometry on the balance beam performance of Young Gymnasts,"Journal of Contemporary Kinesiology, 2017, pp. 104-114.

[2] M. Olaru, "Selection in Artistics Gymnastics." Timisoara Physical Education and Rehabilitation Journal, 2009, Vol I. Timisoara: West University

[3] E. R. Sukamti. Pengembangan Model Pemanduan Bakat Senam Artistik Usia Dini (Disertasi). Yogykarta: UNY, 2016.

[4] Sugiyono, Metode penelitian kuantitatif, kualitatif dan RnD. Bandung: Alfabeta, 2011. 